\title{
Effect of seeding rate on selected physical parameters and biomass yield of maize
}

\author{
Andrzej Anders ${ }^{1 *}$, Piotr Markowski ${ }^{1}$, Stanislaw Konopka ${ }^{1}$, Zdzislaw Kaliniewicz $^{1}$, \\ Adam Józef Lipinski ${ }^{1}$, and Dariusz Jan Choszcz ${ }^{1}$
}

${ }^{1}$ University of Warmia and Mazury in Olsztyn, Department of Heavy Duty Machines and Research Methodology, ul. Oczapowskiego 11, 10-719 Olsztyn, Poland. *Corresponding author (anders@uwm.edu.pl).

Received: 15 October 2019; Accepted: 7 January 2020; doi:10.4067/S0718-58392020000200171

\begin{abstract}
Plant morphology is affected by plant density and uniformity of plant distribution per unit area. This study investigates the effect of seeding rate of two hybrid cultivars of maize (Zea mays L.) harvested for silage on selected physical parameters (stem length, stem diameter, total plant weight and weight of ears with husks), fresh weight yield and ear yield of maize plants. A field experiment was carried out in 2011-2013 on soil of weak rye complex ('Kosmo') and a good rye complex ('Kixxo'). Results were processed by one-way ANOVA, correlation analysis and regression analysis. At constant $0.75 \mathrm{~m}$ inter-row spacing, seeding rate (6.5 to 11.9 seeds $\mathrm{m}^{-2}$ for 'Kosmo' and 8 to 12 seeds $\mathrm{m}^{-2}$ for 'Kixxo') significantly $(\alpha=0.05)$ influenced evaluated parameters. Higher plant density lowered the weight of plants and ears, and resulted in lower stem diameter. An increase in seeding rate led to a decrease in stem diameter measured at 50, 100 and $150 \mathrm{~cm}$ above ground (by ca. $11 \%$ to $23 \%$ in 'Kosmo', and by $c a .3 \%$ to $13 \%$ in 'Kixxo'), and an increase in stem length (by $10 \%$ to $13 \%$ in 'Kosmo', and by $c a .8 \%$ in 'Kixxo'). Plants grown with lower seeding rates were larger and heavier. The developed equations are characterized by a good and very good fit to empirical data (multiple correlation coefficient ranged from 0.62 to 0.94 in 'Kosmo', and from 0.76 to 0.95 in 'Kixxo'). This knowledge of the morphological traits of maize is useful to optimize operating parameters of harvesting machines.
\end{abstract}

Key words: Ear yield, maize, physical parameters of plants, regression equations, total yield.

\section{INTRODUCTION}

Maize (Zea mays L.) is the highest-yielding cereal and one of the most widely cultivated cereal species in the world next to wheat and rice. In 2017 global maize yield topped 1100 million tons. The popularity of maize has also been growing steadily in Poland in recent years. Maize is grown for forage (whole-plant silage and corn cob mix), food and energy generation (Kusmirek et al., 2011; Kovács and Kerényi, 2019).

Maize is one of the highest-yielding and most versatile cereals. In Poland, it is usually grown on soils of very good and good rye complex. In the last $3 \mathrm{yr}$, average grain yields exceeded $7 \mathrm{t} \mathrm{ha}^{-1}$ (GUS, 2018). Seed sowing technology is one of the most important determinants of maize yield. Timely planting, uniform sowing (in horizontal and vertical orientation in the field), adequate soil preparation, fertilization and plant treatments contribute to plant growth and increase yield (Kowalczuk et al., 2012). Most of the current studies related to the cultivation of maize concerns the impact of local abiotic factors (mainly water deficiency) on grain yield and DM in the vegetative and reproductive stage (Yazar et al., 2009; Oveysi et al., 2010; Mi et al., 2018).

Plant distribution and plant density per unit area influence yield, as well as the morphological characteristics of crops (Ahmad et al., 2012; Bieniaszewski et al., 2012; Król, 2013). The morphological traits of plants affect their resistance to 
bending and cutting, and -indirectly- the amount of energy needed to harvest and process crops. A sound knowledge of plant morphology is required for designing agricultural machinery and programming the operating parameters of farm machines (Ince et al., 2005). Efforts have been made to model the shape and select the appropriate operating parameters of cutting and shredding units in combine harvesters and forage harvesters to reduce cutting energy and improve the cutting and shredding quality of maize plants - stems and ears (Igathinathane et al., 2010; Qin et al., 2020). The shape of feeder beater blades and the size of working clearance in flywheel cutting/chopping units have also been investigated (Lisowski et al., 2008a; 2008b).

The effect of vertical and horizontal seed distribution, plant density, $\mathrm{N}$ fertilization, precipitation and plant vigor on yield and yield components has been widely discussed in the literature (Liu et al., 2004; Sowinski and Liszka-Podkowa, 2008; Cilia et al., 2014; Wei et al., 2017). However, the influence of the above factors on mutual relationships between the physical parameters of crop plants, including maize, remains insufficiently researched. Susceptibility to lodging is one of the factors that contribute to lower grain yields in maize (Huang et al., 2016). Lodging is related to stem diameter at base, stem length, stem wall thickness and plant weight. Similarly to the structural parameters of maize plants, the above characteristics have been relatively poorly investigated to date (Stubbs et al., 2019). The cross-section of maize stems shows that they are flattened tubes filled with pith. It has also been found that the fibers located in the outer layer (rind) are responsible for stalk strength and stiffness. The number and stiffness of fibers changes with plant height (Huang et al., 2016; Stubbs et al., 2019). The mechanical properties of maize stalks are also affected by water content (Zhang et al., 2017).

The aim of this study was to determine the effect of seeding rate (plant density) on selected physical parameters (stem length, stem diameter, plant weight, weight of ears with husks), total yield and ear yield of maize harvested for silage. Relationships (regression equations) between seeding rate (plant density) and the morphological traits of maize plants were also analyzed because they can be used to design assemblies and subassemblies of machines for harvesting and postharvest processing of maize, and to optimize their operating parameters.

\section{MATERIALS AND METHODS}

A field experiment was carried out in 2011-2013 on soils of good and weak rye complex, classified as sand and loamy sand according to the USDA classification system (Soil Survey Staff, 2006). Soil was moderately abundant in nutrients (available $\mathrm{P}, \mathrm{K}$ and $\mathrm{Mg}$ ), and it had a near-neutral $\mathrm{pH}$. Two maize cultivars, recommended for silage production in the climate of central and central-northern Poland, were examined: Kosmo 230 (FAO 240) and RGT Kixxo (FAO 210-230). 'Kosmo' was cultivated on a farm in Marszewnica (5310' N, $19^{\circ} 57^{\prime}$ E, $152 \mathrm{~m}$ a.s.l.), Lidzbark Welski municipality, Działdowo county, Region of Warmia and Mazury, on soil classified as sand according to the USDA classification system, regarded as highly vulnerable to drought - water availability < $127.5 \mathrm{~mm}$ (Doroszewski et al., 2012). 'Kixxo' was grown on a farm in Perzanowo (52 $88^{\prime}$ N, $21^{\circ} 25^{\prime}$ E, 152 m a.s.1.), Czerwonka municipality, Maków Mazowiecki county, Region of Mazowsze, on soil classified as loamy sand according to the USDA classification system, regarded as vulnerable to drought - water availability 127.5-169.9 mm (Doroszewski et al., 2012). The experiment was established on soils of medium and poor quality, which account for over $40 \%$ of total arable land area in Poland and are used mostly for maize cultivation.

Maize was sown in the second half of April with inter-row spacing of $0.75 \mathrm{~m}$ and the following seeding rates: 'Kosmo' 6.5, 8.3, 9.5, 10.7 and 11.9 seeds $\mathrm{m}^{-2}$, 'Kixxo' 8, 9, 10, 11 and 12 seeds $\mathrm{m}^{-2}$. Seeding parameters were identical for both maize cultivars and the adopted seeding rates: seeding depth was $6 \mathrm{~cm}$ and seeding speed was $2.25 \mathrm{~m} \mathrm{~s}^{-1}$. Constant seeding parameters were applied to eliminate their effect on the distance between seeds in rows and ensure adequate plant density. Manure was applied at $25 \mathrm{t} \mathrm{ha}^{-1}$ in August of the year preceding the experiment. Mineral fertilizers were applied at the following rates: $80 \mathrm{~kg} \mathrm{~N}^{-1}$ (pre-sowing) and $15 \mathrm{~kg} \mathrm{ha}^{-1}$ urea dissolved in water with $5 \mathrm{~L}$ phosphate fertilizer (Wuxal top P, Aglukon, Düsseldorf, Germany) at 6-7 unfolded leaves (BBCH 16), $115 \mathrm{~kg} \mathrm{P} \mathrm{ha}^{-1}$ and $120 \mathrm{~kg} \mathrm{~K} \mathrm{ha}^{-1}$ (pre-sowing). After sowing, weeds were controlled with two herbicides: bromoxynil+terbuthlazine (Zeagran 340 SE; Nufarm, Warsaw, Mazowsze, Poland) at $1 \mathrm{~L} \mathrm{ha}^{-1}$ and nicosulfuron (Milagro Extra 6 OD; ISK Biosciences Europe S.A, Diegem, Belgium) at $0.75 \mathrm{~L} \mathrm{ha}^{-1}$. Maize was harvested for silage at the dough stage (BBCH 85) in the second half of September. The plants were analyzed to determine their structural and morphometric parameters, fresh weight yield and yield of ears with husks. 
Selected physical parameters of maize plants (stem length, stem diameter, total plant weight and ear weight) were measured immediately before harvest in three replicates, along rows, with a row spacing of $30 \mathrm{~m}$. Stem diameter was measured in 10-m-long sections, with a digital caliper to the nearest $1 \mathrm{~mm}$, at three heights above ground $(50,100$ and 150 $\mathrm{cm}$ ), in two mutually perpendicular planes. If nodes were detected at the examined height, measurements were performed directly above the node at a distance of around $3 \mathrm{~cm}$. Stem length was measured to the nearest $1 \mathrm{~cm}$ between the ground and inflorescence. Whole plant weight and weight of ears with leaves were determined using a precision balance (WLC 6/A2/C/2; RADWAG, North Miami Beach, Florida, USA) with maximum capacity of $6 \mathrm{~kg}$ and readability of $\pm 0.1 \mathrm{~g}$. Before measurement, maize stems were cut into $c a .40-50 \mathrm{~cm}$ segments with bypass loppers.

The results of measurements and calculations were processed statistically in the STATISTICA v. 12.5 program (TIBCO Software, Palo Alto, California, USA) with the use of descriptive statistical methods, nonparametric tests, correlation analysis and multiple regression analysis (Rabiej, 2012; Konopka and Markowski, 2016). The Kruskal-Wallis test was performed to determine significant differences between the analyzed parameters when empirical data were not normally distributed. This test is conducted when the analyzed trait does not have normal distribution and does not meet the assumption of homogeneity of variance. To derive a regression equation characterized by the best fit between the empirical data and the model, curvilinear quintic equations, multivariate equations, quadratic polynomial equations involving multiple variables and exponential equations were tested, followed by a regression analysis with backward elimination and stepwise selection. The influence of seeding rate on selected physical parameters of maize plants was determined in ANOVA. All calculations were performed at a significance level of 0.05.

\section{RESULTS}

Selected physical parameters of maize plants (stem length, stem diameter, total plant weight, weight of ears with husks) at the analyzed seeding rates are presented in Tables 1 and 2. A comparison of mean and median values points to small differences which did not exceed 3\% for 'Kosmo' and 4\% for 'Kixxo'. In 'Kosmo', stem length was the least varied parameter ( $c a .5 \%-9 \%)$. The average variation in stem diameter, described by the coefficient of variation, at 50, 100 and $150 \mathrm{~cm}$ above ground, was determined at $15.4 \%, 18.8 \%$ and $22.2 \%$, respectively. Plant weight was the most varied attribute with an average coefficient of variation of $33.2 \%$. Slightly lower variation (29.3\%) was noted in the weight of ears with husks. In 'Kixxo', the coefficient of variation for stem length was similar at approximately 7\%-9\%. Stem diameter, measured at 50,100 and $150 \mathrm{~cm}$ above ground, was determined at $11.5 \%, 12.4 \%$ and $15 \%$, respectively, and it was significantly less varied than in 'Kosmo'. The variations in total plant weight and ear weight in the evaluated maize cultivars were similar at $26.7 \%$ and $31.7 \%$, respectively.

The results of ANOVA for stem length, stem diameter, total plant weight and ear weight are presented in Table 3. In all cases, maize plants sown at various seeding rates differed in their physical parameters (Table 3 ). In view of the above, hypothesis $\mathrm{H}_{0}$ postulating that mean values of selected physical parameters of maize plants are equal at five seeding rates was rejected, and the alternative hypothesis $\mathrm{H}_{1}$ was adopted.

A linear correlation analysis of the physical parameters of maize plants 'Kosmo' (Table 4) revealed that plant density was most highly correlated with ear weight (with husks) at -0.45 . Plant weight and stem diameter at $50 \mathrm{~cm}$ above ground were also negatively correlated with seeding rate at -0.21 and -0.18 , respectively. Seeding rate did not exert a significant influence on stem diameter at 100 and $150 \mathrm{~cm}$ above ground, and the relevant correlation coefficients were determined at -0.03 and -0.08 , respectively. The only physical attribute that was positively correlated with plant density was stem length (0.28). Relatively high correlation coefficients (above 0.5 ) were noted between stem diameters measured 50, 100 and $150 \mathrm{~cm}$ above ground, and between total plant weight and ear weight (0.84). In 'Kixxo', seeding rate was most highly correlated with stem diameter measured 50,100 and $150 \mathrm{~cm}$ above ground at $-0.24,-0.32$ and -0.26 , respectively. Seeding rate had a smaller, but significant influence on ear weight and total plant weight, and relevant correlation coefficients were determined at -0.15 and -0.14 , respectively. In 'Kixxo', stem length was the only physical attribute that was not correlated with seeding rate (-0.03). Similarly to the first cultivar, high correlation coefficients (above 0.77 ) were noted between stem diameters measured 50,100 and $150 \mathrm{~cm}$ above ground, and between total plant weight and ear weight (0.9). 
Table 1. Statistical parameters of distribution for selected physical parameters of maize 'Kosmo'.

\begin{tabular}{|c|c|c|c|c|c|c|}
\hline \multirow{2}{*}{$\begin{array}{l}\text { Physical parameters } \\
\text { of maize plants }\end{array}$} & \multirow[b]{2}{*}{ Statistical parameters } & \multicolumn{5}{|c|}{ Seeding rate (seeds $\mathrm{m}^{-2}$ ) } \\
\hline & & 6.5 & 8.3 & 9.5 & 10.7 & 11.9 \\
\hline \multirow[t]{4}{*}{ Stem length, $\mathrm{cm}$} & Mean & 213.1 & 215.0 & 240.3 & 233.9 & 223.5 \\
\hline & Median & 214.0 & 217.0 & 240.0 & 239.0 & 229.0 \\
\hline & Standard deviation & 18.2 & 16.5 & 11.6 & 21.9 & 14.8 \\
\hline & Coefficient of variation (\%) & 8.52 & 7.66 & 4.84 & 9.37 & 6.61 \\
\hline \multirow{4}{*}{$\begin{array}{l}\text { Stem diameter at } 50 \mathrm{~cm} \\
\text { above ground, } \mathrm{cm}\end{array}$} & Mean & 20.6 & 18.9 & 23.2 & 19.1 & 17.5 \\
\hline & Median & 20.0 & 19.0 & 24.0 & 19.0 & 18.0 \\
\hline & Standard deviation & 3.2 & 2.6 & 3.9 & 2.8 & 2.5 \\
\hline & Coefficient of variation (\%) & 15.68 & 13.98 & 16.87 & 14.84 & 14.35 \\
\hline \multirow{4}{*}{$\begin{array}{l}\text { Stem diameter at } 100 \mathrm{~cm} \\
\text { above ground, } \mathrm{cm}\end{array}$} & Mean & 15.5 & 14.8 & 18.1 & 15.3 & 13.9 \\
\hline & Median & 15.0 & 15.0 & 18.0 & 15.0 & 14.0 \\
\hline & Standard deviation & 2.7 & 2.7 & 3.8 & 2.9 & 2.5 \\
\hline & Coefficient of variation (\%) & 17.68 & 18.07 & 21.08 & 19.05 & 18.08 \\
\hline \multirow{4}{*}{$\begin{array}{l}\text { Stem diameter at } 150 \mathrm{~cm} \\
\text { above ground, } \mathrm{cm}\end{array}$} & Mean & 11.6 & 11.0 & 13.3 & 11.1 & 10.4 \\
\hline & Median & 12.0 & 11.0 & 12.0 & 11.0 & 10.0 \\
\hline & Standard deviation & 2.7 & 2.4 & 3.1 & 2.4 & 2.1 \\
\hline & Coefficient of variation (\%) & 23.51 & 21.60 & 23.60 & 21.66 & 20.49 \\
\hline \multirow[t]{4}{*}{ Total plant weight, $\mathrm{kg}$} & Mean & 0.566 & 0.512 & 0.565 & 0.536 & 0.427 \\
\hline & Median & 0.541 & 0.495 & 0.546 & 0.526 & 0.424 \\
\hline & Standard deviation & 0.188 & 0.168 & 0.187 & 0.180 & 0.138 \\
\hline & Coefficient of variation (\%) & 33.147 & 32.857 & 33.184 & 33.667 & 33.334 \\
\hline \multirow[t]{4}{*}{ Ear weight, $\mathrm{kg}$} & Mean & 0.282 & 0.242 & 0.256 & 0.218 & 0.192 \\
\hline & Median & 0.280 & 0.245 & 0.250 & 0.216 & 0.198 \\
\hline & Standard deviation & 0.075 & 0.066 & 0.056 & 0.064 & 0.067 \\
\hline & Coefficient of variation (\%) & 26.680 & 27.228 & 26.416 & 29.534 & 36.713 \\
\hline
\end{tabular}

Table 2. Statistical parameters of distribution for selected physical parameters of maize 'Kixxo'.

\begin{tabular}{|c|c|c|c|c|c|c|}
\hline \multirow{2}{*}{$\begin{array}{l}\text { Physical parameters } \\
\text { of maize plants }\end{array}$} & \multirow[b]{2}{*}{ Statistical parameters } & \multicolumn{5}{|c|}{ Seeding rate (seeds $\mathrm{m}^{-2}$ ) } \\
\hline & & 8 & 9 & 10 & 11 & 12 \\
\hline \multirow[t]{4}{*}{ Stem length, cm } & Mean & 263.1 & 263.8 & 289.3 & 285.3 & 283.9 \\
\hline & Median & 266.0 & 268.0 & 296.0 & 286.0 & 292.0 \\
\hline & Standard deviation & 22.4 & 20.1 & 26.5 & 23.2 & 19.9 \\
\hline & Coefficient of variation $(\%)$ & 8.51 & 7.61 & 9.17 & 8.14 & 6.94 \\
\hline \multirow{4}{*}{$\begin{array}{l}\text { Stem diameter at } 50 \mathrm{~cm} \\
\text { above ground, } \mathrm{cm}\end{array}$} & Mean & 19.3 & 18.6 & 18.4 & 18.3 & 17.5 \\
\hline & Median & 19.5 & 18.5 & 18.0 & 18.5 & 17.5 \\
\hline & Standard deviation & 2.0 & 1.9 & 2.4 & 2.4 & 2.1 \\
\hline & Coefficient of variation $(\%)$ & 10.22 & 9.96 & 12.81 & 13.02 & 11.72 \\
\hline \multirow{4}{*}{$\begin{array}{l}\text { Stem diameter at } 100 \mathrm{~cm} \\
\text { above ground, } \mathrm{cm}\end{array}$} & Mean & 16.5 & 15.5 & 14.7 & 15.0 & 14.3 \\
\hline & Median & 16.5 & 15.5 & 14.5 & 15.0 & 14.0 \\
\hline & Standard deviation & 1.7 & 1.6 & 2.1 & 1.9 & 2.1 \\
\hline & Coefficient of variation (\%) & 10.53 & 10.02 & 14.62 & 12.71 & 14.33 \\
\hline \multirow{4}{*}{$\begin{array}{l}\text { Stem diameter at } 150 \mathrm{~cm} \\
\text { above ground, } \mathrm{cm}\end{array}$} & Mean & 11.5 & 10.6 & 10.4 & 10.1 & 10.2 \\
\hline & Median & 11.5 & 11.0 & 10.0 & 10.0 & 10.0 \\
\hline & Standard deviation & 1.5 & 1.4 & 1.8 & 1.6 & 1.6 \\
\hline & Coefficient of variation (\%) & 13.02 & 13.14 & 17.44 & 15.74 & 15.37 \\
\hline \multirow[t]{4}{*}{ Total plant weight, $\mathrm{kg}$} & Mean & 0.482 & 0.471 & 0.451 & 0.446 & 0.433 \\
\hline & Median & 0.500 & 0.480 & 0.440 & 0.440 & 0.430 \\
\hline & Standard deviation & 0.112 & 0.110 & 0.139 & 0.128 & 0.119 \\
\hline & Coefficient of variation $(\%)$ & 23.17 & 23.45 & 30.81 & 28.69 & 27.43 \\
\hline \multirow[t]{4}{*}{ Ear weight, $\mathrm{kg}$} & Mean & 0.205 & 0.186 & 0.190 & 0.187 & 0.173 \\
\hline & Median & 0.210 & 0.190 & 0.190 & 0.190 & 0.180 \\
\hline & Standard deviation & 0.062 & 0.056 & 0.059 & 0.062 & 0.059 \\
\hline & Coefficient of variation (\%) & 30.08 & 30.08 & 30.99 & 33.07 & 34.26 \\
\hline
\end{tabular}


Table 3. Significance of differences in the physical parameters of maize.

\begin{tabular}{|c|c|c|c|c|c|c|}
\hline \multirow[b]{2}{*}{ Seeding rate } & \multirow{2}{*}{$\begin{array}{l}\text { Stem } \\
\text { length }\end{array}$} & \multicolumn{3}{|c|}{ Stem diameter-height above ground } & \multirow{2}{*}{$\begin{array}{c}\text { Total plant } \\
\text { weight }\end{array}$} & \multirow{2}{*}{$\begin{array}{c}\text { Ear } \\
\text { weight }\end{array}$} \\
\hline & & $50 \mathrm{~cm}$ & $100 \mathrm{~cm}$ & $150 \mathrm{~cm}$ & & \\
\hline \multirow[t]{2}{*}{ Seeds $\mathrm{m}^{-2}$} & $\mathrm{~cm}$ & $\longrightarrow$ & $\mathrm{mm}$ & & $\longrightarrow$ & 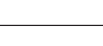 \\
\hline & & \multicolumn{3}{|c|}{ Maize 'Kosmo’ } & & \\
\hline 6.5 & $213.1 d$ & $20.6 b$ & $15.5 b$ & $11.6 b$ & $0.566 \mathrm{a}$ & $0.282 \mathrm{a}$ \\
\hline 8.3 & $215.0 \mathrm{~d}$ & $18.9 \mathrm{c}$ & $14.8 \mathrm{c}$ & $11.0 \mathrm{~b}$ & $0.512 \mathrm{a}$ & $0.242 \mathrm{bc}$ \\
\hline 9.5 & $240.3 \mathrm{a}$ & $23.2 \mathrm{a}$ & $18.1 \mathrm{a}$ & $13.3 \mathrm{a}$ & $0.565 \mathrm{a}$ & $0.257 \mathrm{ab}$ \\
\hline 10.7 & $233.9 b$ & $19.1 \mathrm{c}$ & $15.3 \mathrm{bc}$ & $11.1 \mathrm{~b}$ & $0.536 \mathrm{a}$ & $0.218 \mathrm{~cd}$ \\
\hline \multirow[t]{2}{*}{11.9} & $223.5 \mathrm{c}$ & $17.5 \mathrm{~d}$ & $13.9 \mathrm{~d}$ & $10.4 \mathrm{c}$ & $0.427 \mathrm{~b}$ & $0.192 d$ \\
\hline & & \multicolumn{3}{|c|}{ Maize 'Kixxo' } & & \\
\hline 8.0 & $263.1 \mathrm{~b}$ & $19.3 \mathrm{a}$ & $16.5 \mathrm{a}$ & $11.5 \mathrm{a}$ & $0.482 \mathrm{a}$ & $0.205 \mathrm{a}$ \\
\hline 9.0 & $263.8 \mathrm{~b}$ & $18.6 \mathrm{ab}$ & $15.5 b$ & $10.6 b$ & $0.471 \mathrm{ab}$ & $0.186 \mathrm{ab}$ \\
\hline 10.0 & $289.3 \mathrm{a}$ & $18.4 \mathrm{~b}$ & $14.7 \mathrm{~cd}$ & $10.4 \mathrm{~b}$ & $0.451 \mathrm{ab}$ & $0.190 \mathrm{ab}$ \\
\hline 11.0 & $285.3 \mathrm{a}$ & $18.3 \mathrm{~b}$ & $15.0 \mathrm{bc}$ & $10.1 \mathrm{~b}$ & $0.446 \mathrm{ab}$ & $0.187 \mathrm{ab}$ \\
\hline 12.0 & $283.9 \mathrm{a}$ & $17.5 \mathrm{c}$ & $14.3 \mathrm{~d}$ & $10.2 \mathrm{~b}$ & $0.433 b$ & $0.173 b$ \\
\hline
\end{tabular}

Different letters denote significant differences at $\alpha=0.05$.

Table 4. Coefficients of linear correlation between the physical parameters of maize and seeding rate.

\begin{tabular}{|c|c|c|c|c|c|c|c|c|}
\hline \multirow[b]{2}{*}{ Cultivar } & \multirow[b]{2}{*}{$\begin{array}{c}\text { Physical } \\
\text { trait }\end{array}$} & \multirow[b]{2}{*}{$\begin{array}{l}\text { Seeding } \\
\text { rate } \\
(\mathrm{g})\end{array}$} & \multirow[b]{2}{*}{$\begin{array}{l}\text { Stem } \\
\text { length } \\
\text { (h) }\end{array}$} & \multicolumn{3}{|c|}{$\begin{array}{l}\text { Stem diameter - height } \\
\text { above ground }\end{array}$} & \multicolumn{2}{|c|}{ Weight } \\
\hline & & & & $\begin{array}{c}50 \mathrm{~cm} \\
\left(\varphi_{50}\right)\end{array}$ & $\begin{array}{c}100 \mathrm{~cm} \\
\left(\varphi_{100}\right)\end{array}$ & $\begin{array}{c}150 \mathrm{~cm} \\
\left(\varphi_{150}\right)\end{array}$ & $\begin{array}{l}\text { Ear } \\
\left(\mathrm{m}_{\mathrm{k}}\right)\end{array}$ & $\begin{array}{c}\text { Plant } \\
\left(\mathrm{m}_{\mathrm{r}}\right)\end{array}$ \\
\hline \multirow[t]{7}{*}{ Kosmo } & $\mathrm{g}$ & 1.0000 & 0.2751 & -0.1754 & -0.0274 & -0.0751 & -0.4449 & -0.2147 \\
\hline & $\mathrm{h}$ & & 1.0000 & 0.4224 & 0.5142 & 0.4435 & -0.0060 & 0.1517 \\
\hline & $\varphi_{50}$ & & & 1.0000 & 0.7818 & 0.4990 & 0.3087 & 0.2888 \\
\hline & $\varphi_{100}$ & & & & 1.0000 & 0.6718 & 0.2380 & 0.3186 \\
\hline & $\varphi_{150}$ & & & & & 1.0000 & 0.1401 & 0.1618 \\
\hline & $\mathrm{m}_{\mathrm{k}}$ & & & & & & 1.0000 & 0.8384 \\
\hline & $\mathrm{m}_{\mathrm{r}}$ & & & & & & & 1.0000 \\
\hline \multirow[t]{7}{*}{ Kixxo } & $\mathrm{g}$ & 1.0000 & -0.0315 & -0.2433 & -0.3274 & -0.2572 & -0.1527 & -0.1421 \\
\hline & $\mathrm{h}$ & & 1.0000 & 0.4342 & 0.5024 & 0.5080 & 0.5214 & 0.4974 \\
\hline & $\varphi_{50}$ & & & 1.0000 & 0.8739 & 0.7740 & 0.8146 & 0.8565 \\
\hline & $\varphi_{100}$ & & & & 1.0000 & 0.7999 & 0.7768 & 0.8214 \\
\hline & $\varphi_{150}$ & & & & & 1.0000 & 0.7205 & 0.7595 \\
\hline & $\mathrm{m}_{\mathrm{k}}$ & & & & & & 1.0000 & 0.8973 \\
\hline & $\mathrm{m}_{\mathrm{r}}$ & & & & & & & 1.0000 \\
\hline
\end{tabular}

Values in bold indicate that the correlation coefficient exceeds the critical value.

$\mathrm{g}$ : Seeding rate $\left(\right.$ seeds $\left.\mathrm{m}^{-2}\right)$; : stem length $(\mathrm{cm}) ; \varphi$ : stem diameter $(\mathrm{mm}) ; \mathrm{m}_{\mathrm{k}}$ : weight of ears with husks $(\mathrm{kg}) ; \mathrm{m}_{\mathrm{r}}$ : weight of maize plants $(\mathrm{kg})$.

The equations describing the effect of seeding rate on the physical parameters of maize plants are presented in Figures 1 and 2. In 'Kosmo', the highest value of the multiple correlation coefficient was noted for ear weight and total plant weight at 0.94 and 0.81 , respectively, and the lowest - for stem diameter measured at 50,100 and $150 \mathrm{~cm}$ above ground at approximately 0.63 . The equations were plotted to reveal that the seeding rate of 10 seeds $\mathrm{m}^{-2}$ produced plants with the longest stems $(232.1 \mathrm{~cm})$, and seeding rates of 8.5 to $8.8 \mathrm{~m}^{-2}$ were responsible for stems with the largest diameters whose values differed subject to height above ground $(50,100$ and $150 \mathrm{~cm})$ and were determined at approximately 21, 16 and 12 $\mathrm{mm}$, respectively. Similarly to the first cultivar, the highest value of the multiple correlation coefficient (0.95) in 'Kixxo' was observed for ear weight and total plant weight. The lowest value of the correlation coefficient $(0.77)$ was noted for stem diameters at 50 and $150 \mathrm{~cm}$ above ground. The equations were plotted to reveal that the seeding rate of 11 seeds $\mathrm{m}^{-2}$ produced plants with the longest stems $(286.1 \mathrm{~cm})$, and that seeding rates of 8.0 to 9.1 seeds $\mathrm{m}^{-2}$ were responsible for the thickest stems. Stem diameters varied subject to height above ground $(50,10$ and $150 \mathrm{~cm})$ and were determined at 19, 16 and $11 \mathrm{~mm}$, respectively. The noted results were similar in both maize cultivars, which points to their similar response to seeding rates. 
Figure 1. Effect of seeding rate on selected physical parameters of maize 'Kosmo': stem length (a), stem diameter at 50 (b), 100 (c) and $150 \mathrm{~cm}$ (d) above ground, ear weight (e), and plant weight (f).
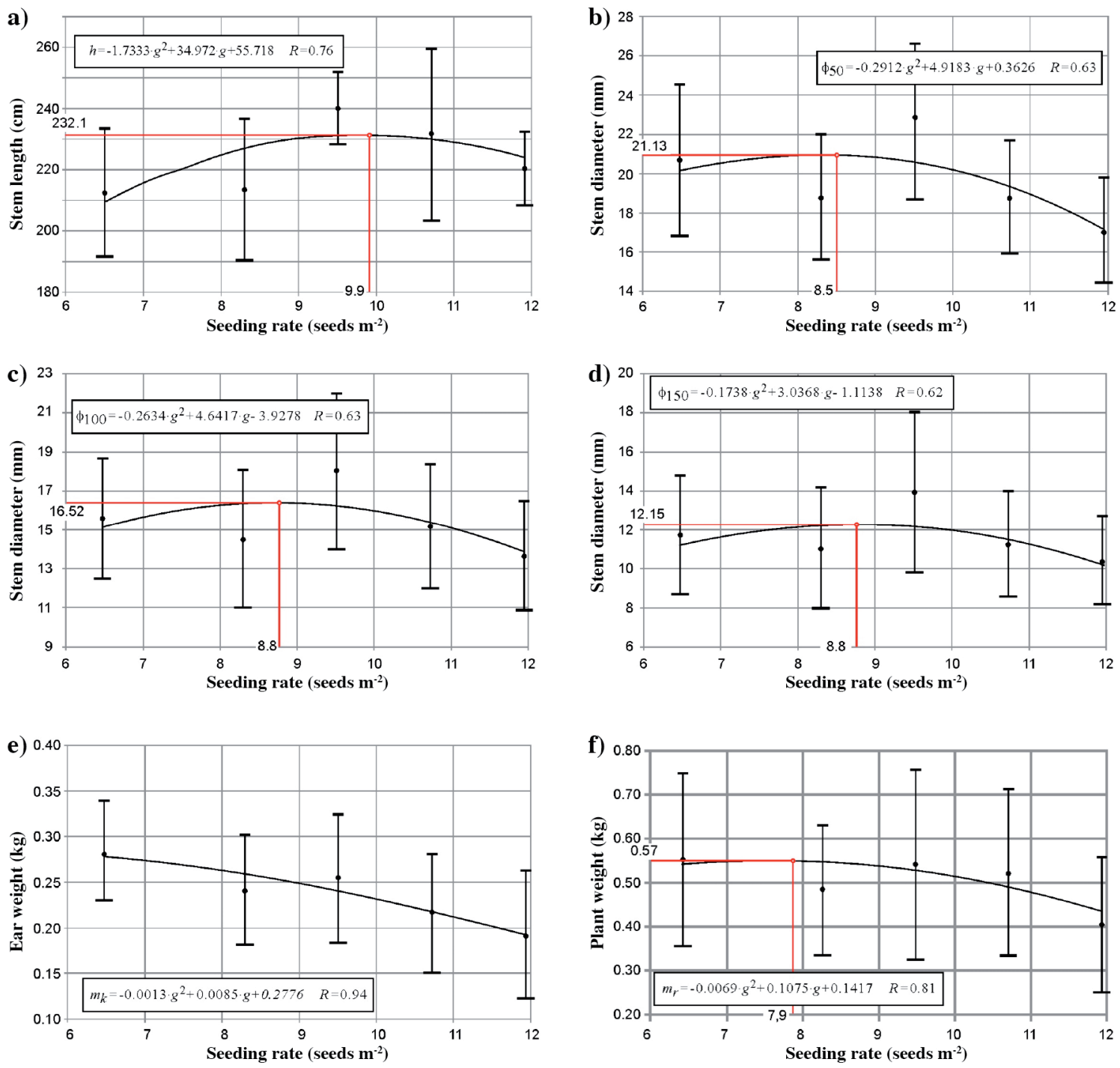
Figure 2. Effect of seeding rate on selected physical parameters of maize 'Kixxo': stem length (a), stem diameter at 50 (b), 100 (c) and $150 \mathrm{~cm}$ (d) above ground, ear weight (e), and plant weight (f).
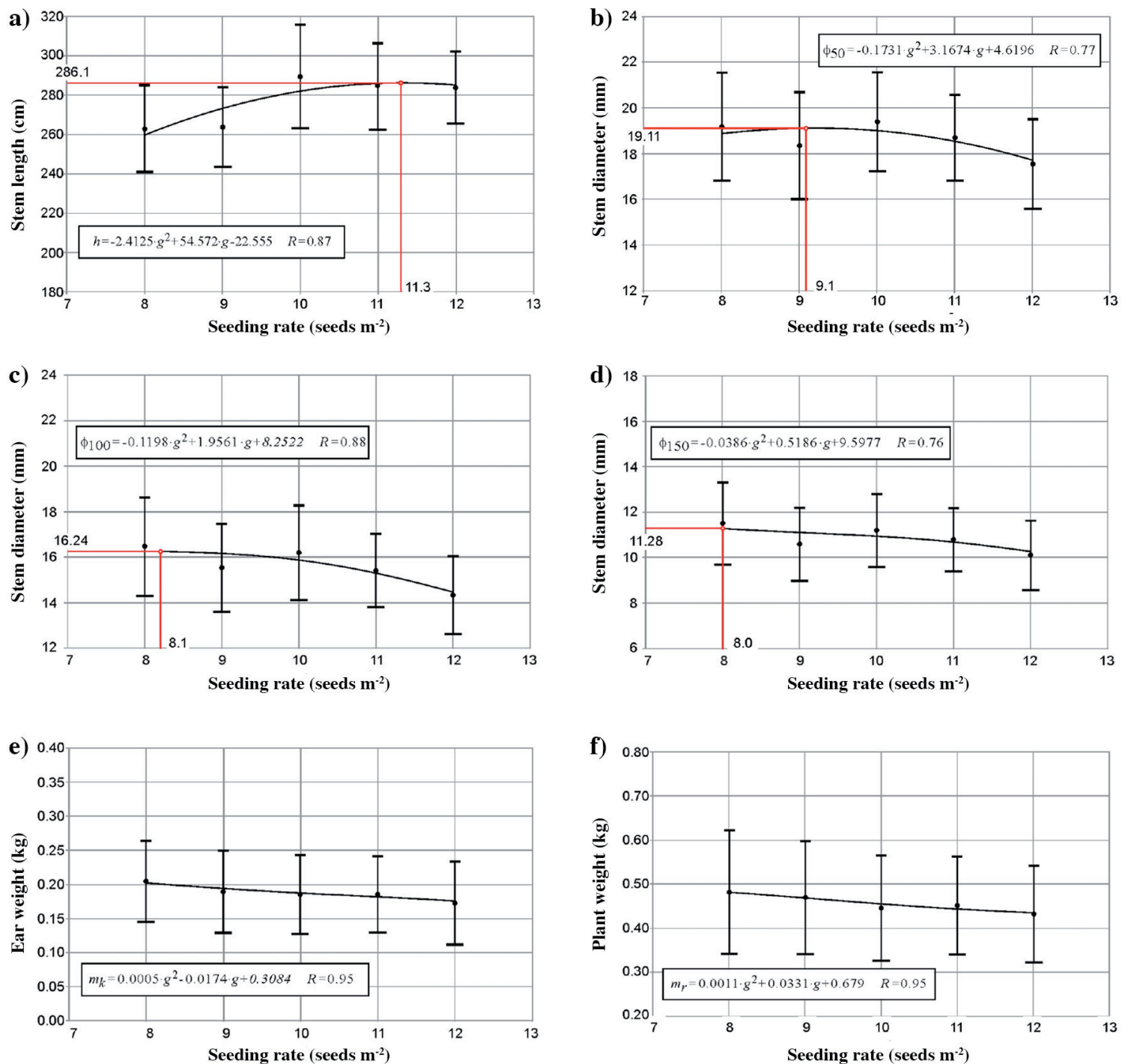

Total yield and ear yield (with husks) at different seeding rates are presented in Figures 3 and 4. In 'Kosmo', the highest green fodder (fresh weight) yield (combined ear and stem yield) of more than $54 \mathrm{t} \mathrm{ha}^{-1}$ was noted at the seeding rate of 11.1 seeds $\mathrm{m}^{-2}$, and the lowest yield of $37 \mathrm{t} \mathrm{ha}^{-1}$ was determined at the lowest seeding rate of $6.5 \mathrm{seeds} \mathrm{m}^{-2}$. Similar trends were observed in ear yield, and the highest ear yield of approximately $23 \mathrm{t} \mathrm{ha}^{-1}$ was determined at the seeding rate of 11.1 seeds $\mathrm{m}^{-2}$. In 'Kixxo', the highest total yield was lower at less than $52 \mathrm{tha}^{-1}$ at the seeding rate of 12 seeds $\mathrm{m}^{-2}$, whereas the lowest yield of $38.5 \mathrm{t} \mathrm{ha}^{-1}$ was noted at the lowest seeding rate of 8 seeds $\mathrm{m}^{-2}$, similarly to 'Kosmo'. In 'Kixxo', ear yield was lower than in 'Kosmo', ranging from 16.4 to $20.8 \mathrm{t} \mathrm{ha}^{-1}$. The highest yield of ears with husks was observed at the highest seeding rate of 12 seeds $\mathrm{m}^{-2}$. 
Figure 3. Effect of seeding rate on the total yield and ear yield of maize 'Kosmo'.

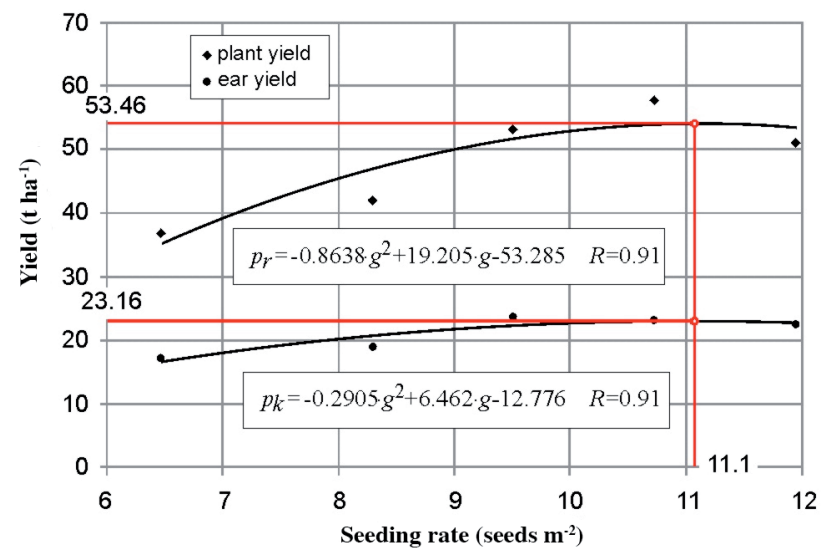

$\mathrm{p}_{\mathrm{k}}$ : Ear yield (with husks, $\left.\mathrm{t} \mathrm{ha}^{-1}\right) ; \mathrm{p}_{\mathrm{r}}$ : green fodder yield $\left(\mathrm{t} \mathrm{ha}^{-1}\right)$.

Figure 4. Effect of seeding rate on the total yield and ear yield of maize 'Kixxo'.

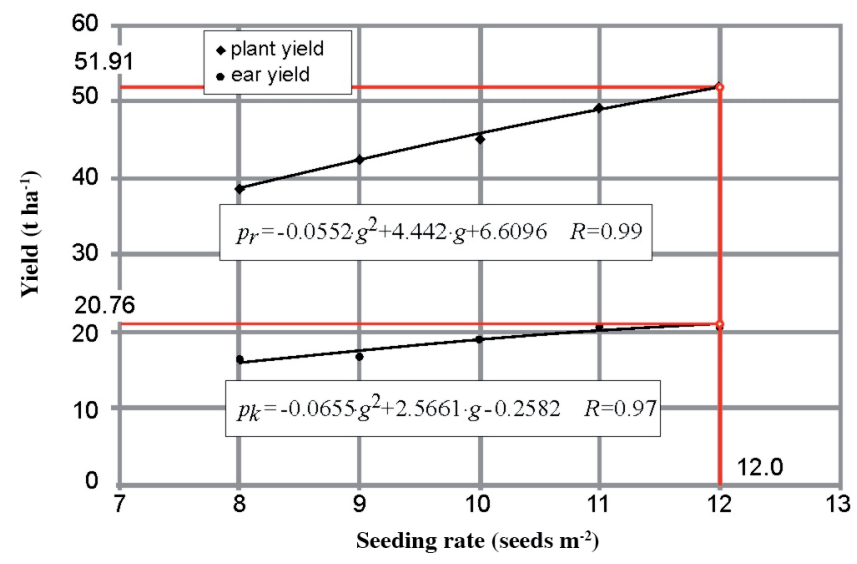

$\mathrm{p}_{\mathrm{k}}$ : Ear yield (with husks, $\left.\mathrm{t} \mathrm{ha}^{-1}\right)$; $\mathrm{p}_{\mathrm{r}}$ : green fodder yield $\left(\mathrm{t} \mathrm{ha}^{-1}\right)$.

\section{DISCUSSION}

In maize, plant density per unit area is a major yield-forming factor next to weather, fertilization rate, crop rotation sequence, physical and chemical properties of soil, and seeding date (Szemplinski et al., 2009; Cilia et al., 2014). High plant density in a stand increases intraspecific competition for light, water and nutrients, which influences plant habit (stem length, stem diameter, leaf area, ear dimensions and ear weight) and the percentage of ear yield in total yield (Hussain et al., 2010; Ahmad et al., 2012; Ksiezak, 2013). In the present study, the stems of 'Kosmo' were significantly $(\alpha=0.05)$ longer when seeding rate was increased from 6.5 to 11.9 seeds $\mathrm{m}^{-2}$. In plants sown at the rate of 9.5 and 10.7 seeds $\mathrm{m}^{-2}$, stem length increased by $10 \%-13 \%$ relative to stands with plant density of 6.5 and 8.3 seeds $\mathrm{m}^{-2}$, and mean stem length increased from 213 to $240 \mathrm{~cm}$. In 'Kixxo', changes in seeding rate also significantly influenced stem length, but the resulting difference was smaller, and it did not exceed $8 \%$. An increase in seeding rate decreased stem diameter at 50, 100 and $150 \mathrm{~cm}$ above ground. In 'Kosmo', higher plant density reduced stem diameter by approximately $11.0 \%-22.5 \%$, 14\%-23\% and 13.0\%-21.8\% at 50, 100 and $150 \mathrm{~cm}$ above ground, respectively. In 'Kixxo', changes in seeding rate led to a less pronounced differences in stem diameter which were determined at $3.4 \%$ to $8.9 \%, 6 \%$ to more than $13 \%$, and approximately $8 \%$ to $12 \%$ at the above heights, respectively.

An increase in plant density significantly reduced the weight of ears with husks. At higher seeding rate, ear weight decreased by 9\%-30\% in 'Kosmo' and by 9\%-16\% in 'Kixxo'. Similar results were reported by Begna et al. (1997), who 
found that increased seeding rates led to a decrease in the weight, length and diameter of ears as well as in the weight and number of kernels per ear in maize grown for grain.

When maize is grown for silage, silage quality is determined mainly by DM content (30\%-35\%) and the percentage of ear yield in total yield (40\%-50\%) (Szemplinski et al., 2009). In our study, the percentage of ear yield in total yield in 'Kosmo' ranged from $44.8 \%$ to $47.5 \%$, which indicates that the harvested green forage was suitable for the production of high quality silage. A certain exception was noted at the seeding rate of 10.7 seeds $\mathrm{m}^{-2}$, where the percentage of ear yield in total yield was only $40.6 \%$, but total ear yield was high at $23.3 \mathrm{t} \mathrm{ha}^{-1}$. A higher ear yield $\left(23.8 \mathrm{tha}^{-1}\right)$ was noted only at the seeding rate of 9.5 seeds $\mathrm{m}^{-2}$. At the remaining seeding rates, ear yield was significantly lower, and it did not exceed $19 \mathrm{t} \mathrm{ha}^{-1}$ at the two lowest seeding rates of 6.5 and 8.3 seeds $\mathrm{m}^{-2}$. In 'Kixxo', the percentage of ear yield in total yield was somewhat lower in the range of $39.4 \%$ to $42.6 \%$. Ear yield was also lower at 16.4 to $20.8 \mathrm{t} \mathrm{ha}^{-1}$, and the highest ear yield was observed at the seeding rate of 11-12 seeds $\mathrm{m}^{-2}$. According to Sulewska (2001), the percentage of ear yield in total yield decreases when the density of maize plants exceeds 10 seeds $\mathrm{m}^{-2}$. This observation is only partially consistent with our findings since in maize 'Kixxo' and 'Kosmo', the percentage of ear yield in total yield decreased by only approximately $2 \%$ and $4 \%$, respectively.

In maize grown for whole-plant silage, plant density usually ranges from 12 to 16 seeds $\mathrm{m}^{-2}$ (Sulewska, 2002). In our study, the above seeding rate proved to be optimal for 'Kixxo'. The highest fresh weight yield was noted at the highest seeding rate of 12 seeds $\mathrm{m}^{-2}$, but the curve had a rising tendency without extreme values of a function (Figure 4), which suggests that fresh weight yield would increase with a further increase in seeding rate. Similar results were noted for ear yield which peaked at nearly $21 \mathrm{t} \mathrm{ha}^{-1}$ at the highest seeding rate of 12 seeds $\mathrm{m}^{-2}$. The curve had a smaller slope, which confirms the observation made by Sulewska (2002) that an increase in seeding rate decreases the percentage of ear yield in green fodder yield and, consequently, lowers silage quality. Our results are also consistent with the findings of Gonet and Siuta (1996) who demonstrated that excessive plant density deteriorates the quality of maize silage due to the increased fiber content of green fodder which adversely affects silage digestibility.

\section{CONCLUSIONS}

An important conclusion is that the seeding rate (plant density) of maize harvested for silage, in the range of 6.5 to 12 seeds $\mathrm{m}^{-2}$, has a significant influence on stem length, stem diameter, plant weight, ear weight, total green fodder yield and ear yield. Seeding rates of approximately 10 and 8.5-8.8 seeds $\mathrm{m}^{-2}$ produce maize plants with the longest stems and the largest diameters, respectively. The highest average weight of a plant (stem + leaves + ear) and an ear with husks can be obtained at seeding rates of 8.5 and 6.5 seeds $\mathrm{m}^{-2}$, respectively ('Kosmo'). In terms of total yield, ear yield and the percentage of ear yield in total green fodder yield, the optimum seeding rate of maize is 11-12 seeds $\mathrm{m}^{-2}$.

The equations derived in the study, which describe the correlations between seeding rate and the physical parameters of maize plants and between seeding rate and the yields of green fodder and ears, could be used to design working units of agricultural machines and to optimize the operating parameters of assemblies and subassemblies of machines for harvesting and post-harvest processing of maize.

\section{REFERENCES}

Ahmad, W., Ahmad, A.U.H., Zamir, M.S.I., Afzal, M., Mohsin, A.U., Khalid, F., et al. 2012. Qualitative and quantitative response of forage maize cultivars to sowing methods under subtropical conditions. Journal of Animal and Plant Sciences 22(2):318-323.

Begna, S.H., Hamilton, R.I., Dwyer, L.M., Stewart, D.W., and Smith, D.L. 1997. Effects of population density on the yield and yield components of leafy reduced-stature maize in short-season areas. Journal of Agronomy and Crop Science 178:103-110.

Bieniaszewski, T., Podlesny, J., Olszewski, J., Stanek, M., and Horoszkiewicz, M. 2012. The response of indeterminate and determinate yellow lupin varieties to different plant density. Fragmenta Agronomica 29(4):7-20.

Cilia, C., Panigada, C., Rossini, M., Meroni, M., Busetto, L., Amaducci, S., et al. 2014. Nitrogen status assessment for variable rate fertilization in maize through hyperspectral imagery. Remote Sensing 6:6549-6565. doi:10.3390/rs6076549.

Doroszewski, A., Jadczyszyn J., Kozyra J., Pudelko R., Stuczynski T., Mizak K., et al. 2012. Fundamentals of the agricultural drought monitoring system. Woda-Środowisko-Obszary Wiejskie [Water-Environment-Rural Areas] 2(38):77-91.

Gonet,Z., and Siuta, A. 1996. The effect of plant density on the yield and feed value of maize grown for green fodder. Yield growth and components. Institute of Soil Science and Plant Cultivation, National Research Institute. Puławy. Poland. 108:19-32. 
GUS. 2018. Crop production in 2018. Information and statistical data, Warszawa, Poland. Statistics Poland (GUS), Warsaw, Poland. Available at https:/stat.gov.pl/obszary-tematyczne/roczniki-statystyczne/roczniki-statystyczne/rocznik-statystyczny-rolnictwa-2018,6,12.html (accessed June 2019).

Huang, J., Liu, W., Zhou, F., Peng Y., and Wang, N. 2016. Mechanical properties of maize fibre bundles and their contribution to lodging resistance. Biosystems Engineering 151:298-307. doi.org/10.1016/j.biosystemseng.2016.09.016.

Hussain, N., Zaman, Q., Nadeem, M.A., and Aziz, A. 2010. Response of maize varieties under agroecological conditions of Dera Ismail Khan. Journal Agricultural Research 48(1):59-63.

Igathinathane, C., Womac, A.R., and Sokhansanj, S. 2010. Corn stalk orientation effect on mechanical cutting. Biosystems Engineering 107:97-106. doi:10.1016/j.biosystemseng.2010.07.005.

Ince, A., Ugurluay, S., Güzel, E., and Özean, M.T. 2005. Bending and shearing characteristics of sunflower stalk residue. Biosystems Engineering 92(2):175-181.

Konopka, S., and Markowski, P. 2016. Methodological aspects of evaluation of the reliability of the research results on the example of measurement of geometric features of seeds of bean. Acta Agrophysica 23(3):421-432. (in Polish).

Kowalczuk, J., Zarajczyk, J., Choszcz, D., Kaliniewicz, Z., and Markowski, P. 2012. New tendencies in construction of precise seeders. Part 1. Technika Rolnicza Ogrodnicza Leśna [Agricultural, Horticultural and Forest Engineering] 5:26-28.

Kovács, Á., and Kerényi, G. 2019. Physical characteristics and mechanical behaviour of maize stalks for machine development. International Agrophysics 33:427-436.

Król, B. 2013. The effect of plant density on the yield and quality of pot marigold (Calendula officinalis L.) Annales Universitatis Mariae Curie-Skłodowska Lublin 68(2):42-49.

Ksiezak, J. 2013. Evaluation of the yield of maize grown for grain in short-term monocultures in different soil types. Fragmenta Agronomica 30(2):103-111.

Kusmirek, E., Rutkowska, B., Szulc, W., and Hoch, M. 2011. Effect of long-term unbalanced mineral fertilization on the content of chosen microelements in the maize grain. Zeszyty Problemowe Postępów Nauk Rolniczych [Advances of Agricultural Sciences Problem Issues] 565:185-189.

Lisowski, A., Klonowski, J., Kostyra, K., Niewęgłowski, K., and Chlebowski, J. 2008a. The impact of the design of flywheel feeder beater blades in cutting unit on the quality and energy consumption of maize plant shredding process. Inżynieria Rolnicza [Agricultural Engineering] 1(99):231-237.

Lisowski, A., Klonowski, J., Kostyra, K., Nowakowski, T., and Sypuła, M. 2008b. Influence of the working clearance of the flywheel chopping unit on the chopping quality and energetic of corn plants. Inżynieria Rolnicza [Agricultural Engineering] 1(99):239-244.

Liu, W., Tollenaar, M., Stewart, G., and Deen, W. 2004: Within-row plant spacing variability does not affect corn yield. Agronomy Journal 96:275-280. doi:10.2134/agronj2004.2750.

Mi, N., Cai, F., Zhang, Y., Ji, R., Zhang, S., and Wang, Y. 2018. Differential responses of maize yield to drought at vegetative and reproductive stages. Plant, Soil and Environment 6(64):260-267.

Oveysi, M., Mirhadi, M.J., Madani, H., Nourmohammadi, G., Zarghami, R., and Madani. A. 2010. The impact of source restriction on yield formation of corn (Zea mays L.) due to water deficiency. Plant, Soil Environment 56(10):476-481.

Qin, J., Yin, Y., Liu, Z., Du, Y., Wang, G., Zhu, Z., et al. 2020. Optimisation of maize picking mechanism by simulation analysis and high-speed video experiments. Biosystems Engineering 189:84-98. doi.org/10.1016/j.biosystemseng.2019.11.010.

Rabiej, M. 2012. Statystyka z programem Statistica [Statisctics in Statistica software]. Helion, Gliwice, Poland.

Soil Survey Staff. 2006. Keys to soil taxonomy. $10^{\text {th }}$ ed. Natural Resources Conservation Service, USDA, Washington D.C.

Sowinski, J., and Liszka-Podkowa, A. 2008. Fresh and dry matter yield quantity and quality of maize (Zea mays L.) and sweet sorghum (Sorghum bicolor (L.) Moench.) on sandy soil depending on nitrogen fertilization. Acta Scientarium Polonorum Agricultura (Agronomia) 7(4):105-115.

Stubbs, C.J., Sun, W., and Cook, D.D. 2019. Measuring the transverse Young's modulus of maize rind and pith tissues. Journal of Biomechanics 84 (2019):113-120. doi.org/10.1016/j.jbiomech.2018.12.028.

Sulewska, H. 2001. The effect of selected agronomic factors on the yield and feed value of maize harvested for green fodder. Roczniki Akademii Rolniczej w Poznaniu, Rozprawy Naukowe [Annals of the University of Life Sciences in Poznań, Scientific Dissertations] 315:1-94.

Sulewska, H. 2002. The effect of selected agronomic factors on the feed value of maize green fodder and whole-plant silage. Institute of Soil Science and Plant Cultivation, National Research Institute, Puławy, Poland 130:701-707.

Szemplinski, W., Bogucka, B., and Wróbel, E. 2009. Suitability of early and mid-early maize hybrids grown in the province of Warmia and Mazury for silage. Acta Scientarium Polonorum Agricultura (Agronomia) 8(1):57-68.

Wei, T., Zhang, T., de Bruin, K., Glomrod, S., and Shi, Q. 2017 Extreme weather impacts on maize yield: The case of Shanxi Province in China. Sustainability 9(41):1-12. doi:10.3390/su9010041.

Yazar, A., Gökcel, F., and Sezen, M.S. 2009. Corn yield response to partial rootzone drying and deficit irrigation strategies applied with drip system. Plant, Soil and Environment 55(11):494-503.

Zhang, K., He, Y., Zhang, H., and Li, H. 2017. Research on mechanical properties of corn stalk. AIP Conference Proceedings 1820:050007. https://doi.org/10.1063/1.4977311. 